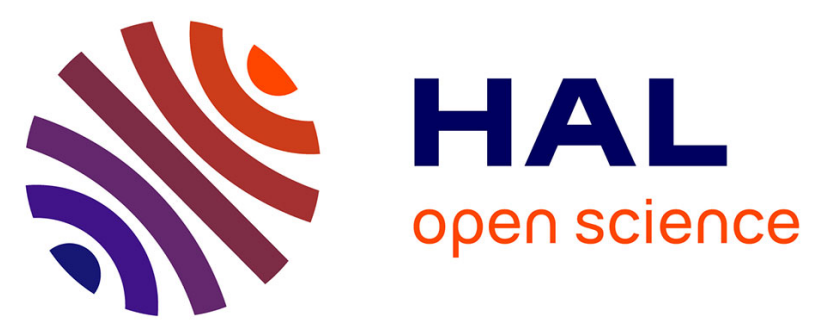

\title{
Influence of small amounts of rhodium on the structure and the reducibility of $\mathrm{Cu} / \mathrm{Al} 2 \mathrm{O} 3$ and $\mathrm{Cu} / \mathrm{CeO} 2-\mathrm{A} 12 \mathrm{O} 3$ catalysts
}

Xavier Courtois, V. Perrichon, M. Primet, G. Bergeret

\section{- To cite this version:}

Xavier Courtois, V. Perrichon, M. Primet, G. Bergeret. Influence of small amounts of rhodium on the structure and the reducibility of $\mathrm{Cu} / \mathrm{Al} 2 \mathrm{O} 3$ and $\mathrm{Cu} / \mathrm{CeO} 2-\mathrm{A} 12 \mathrm{O} 3$ catalysts. Avelino Corma; Francisco V. Melo; Sagrario Mendioroz; José Luis G. Fierro. 12th International Congress on Catalysis. Proceedings of the 12th ICC, 130, Elsevier, pp.1031-1036, 2000, Studies in Surface Science and Catalysis, 978-0-444-50480-7. 10.1016/S0167-2991(00)80334-1 . hal-03109105

\section{HAL Id: hal-03109105 \\ https://hal.science/hal-03109105}

Submitted on 13 Jan 2021

HAL is a multi-disciplinary open access archive for the deposit and dissemination of scientific research documents, whether they are published or not. The documents may come from teaching and research institutions in France or abroad, or from public or private research centers.
L'archive ouverte pluridisciplinaire HAL, est destinée au dépôt et à la diffusion de documents scientifiques de niveau recherche, publiés ou non, émanant des établissements d'enseignement et de recherche français ou étrangers, des laboratoires publics ou privés. 
Stud. Surf. Sci. Catal.130, A. Corma, F.V. Melo, S. Mendioroz and F.L.J. Fierro Editors, (2000) 1031-1036.

DOI: 10.1016/S0167-2991(00)80334-1

\title{
Influence of small amounts of rhodium on the structure and the reducibility of $\mathrm{Cu} / \mathrm{Al}_{2} \mathrm{O}_{3}$ and $\mathrm{Cu} / \mathrm{CeO}_{2}-\mathrm{Al}_{2} \mathrm{O}_{3}$ catalysts.
}

\author{
X. Courtois ${ }^{a}$, V. Perrichon ${ }^{a^{*}}$, M. Primet ${ }^{a}$ and G. Bergeret ${ }^{b}$ \\ ${ }^{\text {a }}$ Laboratoire d'Application de la Chimie à l'Environnement (LACE), UMR 5634 \\ CNRS/Université Claude Bernard Lyon 1, 43 boulevard du 11 Novembre 1918, 69622 \\ Villeurbanne Cedex, France. \\ b Institut de Recherches sur la Catalyse, CNRS, 2, avenue Einstein, 69626 Villeurbanne Cedex, \\ France.
}

The influence of small amounts of rhodium on the structure and the reducibility of copper-based catalysts deposited on alumina and ceria-alumina supports has been studied by $\mathrm{XRD}$ and $\mathrm{H}_{2}$-TPR techniques. For both supports, the addition of rhodium does not affect the reduction mechanism of copper, which has been shown to involve small clusters/isolated ions at lower temperatures and large particles at higher temperatures. However, rhodium addition inhibits the formation of large size copper particles in favor of small ones, thus making easier the reduction of the catalyst at low temperature.

\section{INTRODUCTION}

In the general framework of studying new types of three-way catalysts, copper has been studied as a substitute for automotive post-combustion [1] but seems not active enough without promoter. Considering that rhodium is a key component for the $\mathrm{NO}_{\mathrm{x}}$ elimination, we have looked for the promotional effect of rhodium on the catalytic properties of copper. This study reports on the characterization of supported copper-alumina catalysts and specially on the influence of small amounts of rhodium on their reducibility by hydrogen. Since rhodium is easily reduced, with a reduction temperature lower than that of copper, it is expected to favor the reduction of copper. The influence of a redox support was also investigated by replacing alumina by ceria-alumina, since the surface of ceria is known to be reduced at low temperature in presence of metallic rhodium [2] and consequently may also favor the reduction of copper.

\section{EXPERIMENTAL}

The catalysts were prepared by co-impregnation with nitrate precursors of alumina ( $\mathrm{Al}$, $115 \mathrm{~m}^{2} / \mathrm{g}$ ) and ceria(20\%)-alumina $\left(\mathrm{CeAl}, 95 \mathrm{~m}^{2} / \mathrm{g}\right)$ supports supplied by Rhodia, and calcination at $400^{\circ} \mathrm{C}$ for $6 \mathrm{~h}$ under air. The copper content was $4.75 \mathrm{wt} \%$ and that of rhodium was 100 , 500,1000 and $2000 \mathrm{ppm}$. The corresponding $\mathrm{Cu} / \mathrm{Rh}$ atomic ratio for the bimetallic samples were $760,150,76$ and 38 respectively. 
For the temperature programmed reduction (TPR) experiments, $50 \mathrm{mg}$ of calcined sample were put in a quartz reactor and pretreated in situ under air at $400^{\circ} \mathrm{C}$ for $60 \mathrm{~min}$ and then under $\mathrm{Ar}$ at $500^{\circ} \mathrm{C}$ for $90 \mathrm{~min}$, and finally cooled to room temperature (RT) under $\mathrm{Ar}$.

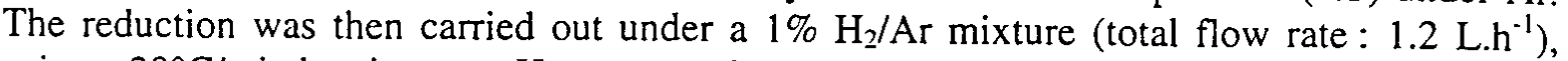
using a $20^{\circ} \mathrm{C} / \mathrm{min}$ heating rate. $\mathrm{H}_{2}$ consumption was detected by thermal conductivity.

Before X-ray diffraction (XRD) experiments, samples were prereduced under $\mathrm{H}_{2}$ at $500^{\circ} \mathrm{C}$ for $6 \mathrm{~h}$, cooled under $\mathrm{H}_{2}$ to $\mathrm{RT}$, then put under $\mathrm{N}_{2}$ and finally slowly exposed to air. Diffraction patterns were obtained with a D500 Siemens goniometer equipped with a diffracted-beam monochromater selecting the $\mathrm{Cu} K \alpha$ radiation $(\lambda=1.5406 \AA)$.

The evolution of the crystalline phases during the reduction was followed by in situ XRD. The experiments were performed on a D500 Siemens diffractometer equipped with a high temperature camera using Mo $\mathrm{K} \alpha \mathrm{Zr}$-filtered radiation $(\lambda=0.7107 \AA)$ and a positive sensitive proportional detector (Raytech). After the standard oxidizing pretreatment, the sample was heated at $20^{\circ} \mathrm{C} / \mathrm{min}$ with a $5 \% \mathrm{H}_{2} / \mathrm{He}$ mixture flowing through the catalyst from $\mathrm{RT}$ to the first reduction temperature (total flow rate : $2.4 \mathrm{~L} . \mathrm{h}^{-1}$ ). After reaching the reduction temperature, the gas flow was changed to He and the sample was allowed to cool to RT. The diffractogram was then recorded. This reduction procedure was repeated on the same sample, increasing the reducing temperature stepwise for subsequent diffractograms.

\section{RESULTS}

Figures 1 and 2 show the XRD patterns for both series of catalysts. The peaks observed at $2 \theta=45.5^{\circ}, 47.3^{\circ}$ and $67.2^{\circ}$ are characteristic of the alumina support and those at $2 \theta=33.0^{\circ}$ and $56.5^{\circ}$ are due to the cubic $\mathrm{CeO}_{2}$ phase. Metallic copper can be detected at $2 \theta=$ $43.3^{\circ}(\mathrm{Cu}(111))$ and $50.4^{\circ}(\mathrm{Cu}(200))$. Rh and $\mathrm{Cu}$ addition induces no detectable change in the structure of the supports but for each type of support the intensity of the two main $\mathrm{Cu}$ peaks decrease when $\mathrm{Rh}$ content increases. On $\mathrm{Al}$ supported catalysts, the $\mathrm{Cu}$ peaks were also clearly detected but only for $\mathrm{Rh}<500 \mathrm{ppm}$.

The TPR profiles of the CuRh/Al catalysts are given Fig. 3. The $\mathrm{Cu} / \mathrm{Al}$ catalyst exhibits two main peaks at $270^{\circ} \mathrm{C}$ and $375^{\circ} \mathrm{C}$, followed by a small shoulder at about $500^{\circ} \mathrm{C}$. The calculation of the $\mathrm{H}_{2}$ consumption up to $800^{\circ} \mathrm{C}$ shows a complete reduction of the deposited copper. The same type of profile was obtained with the $\mathrm{Cu} / \mathrm{CeAl}$ catalyst with two main modifications (Fig. 4) : i) the first peak is broader, because the $\mathrm{CeO}_{2}$ surface in contact with reduced copper is simultaneously reduced [3] and ii) a low $\mathrm{H}_{2}$ consumption is observed from approximately $550^{\circ} \mathrm{C}$ until the end of the test at $800^{\circ} \mathrm{C}$, which is attributed to the reduction of the bulk ceria [4]. As for $\mathrm{Cu} / \mathrm{Al}$, a complete reduction of copper may be assumed on $\mathrm{Cu} / \mathrm{CeAl}$, although the contribution of the ceria reduction makes difficult a precise calculation.

For both supports, the presence of rhodium does not seem to lower the temperature of the beginning of the reduction and does not change the temperature of the peaks. Its main effect is clearly to increase the intensity of the first TPR peak at about $270^{\circ} \mathrm{C}$, whereas the intensity of the second peak at $375^{\circ} \mathrm{C}$ decreases with the Rh content (Figs. 3 and 4 ). With the $\mathrm{CeAl}$ support, the additional broadening of the first peak on the low temperature side can be attributed to the reduction of both rhodium oxide and the ceria surface in contact with rhodium [4]. Note however that for the $\mathrm{CuRh} / \mathrm{Al}$ catalysts where no ceria surface reduction occurs, the contribution of $\mathrm{Rh}$ to the $\mathrm{H}_{2}$ consumption is too low to be detected with our 
apparatus. The small $\mathrm{H}_{2}$ consumption obtained at about $500^{\circ} \mathrm{C}$ for $\mathrm{Cu} / \mathrm{Al}$, which decreases with the $\mathrm{Rh}$ content, could be attributed to the reduction of a surface $\mathrm{Cu}$ aluminate [5]. Finally, with the CuRh2000/Al catalyst, a broad but limited $\mathrm{H}_{2}$ consumption is observed near $600^{\circ} \mathrm{C}$. Its origin is not elucidated yet, but the experiments indicate that it could be linked to the Rh content.

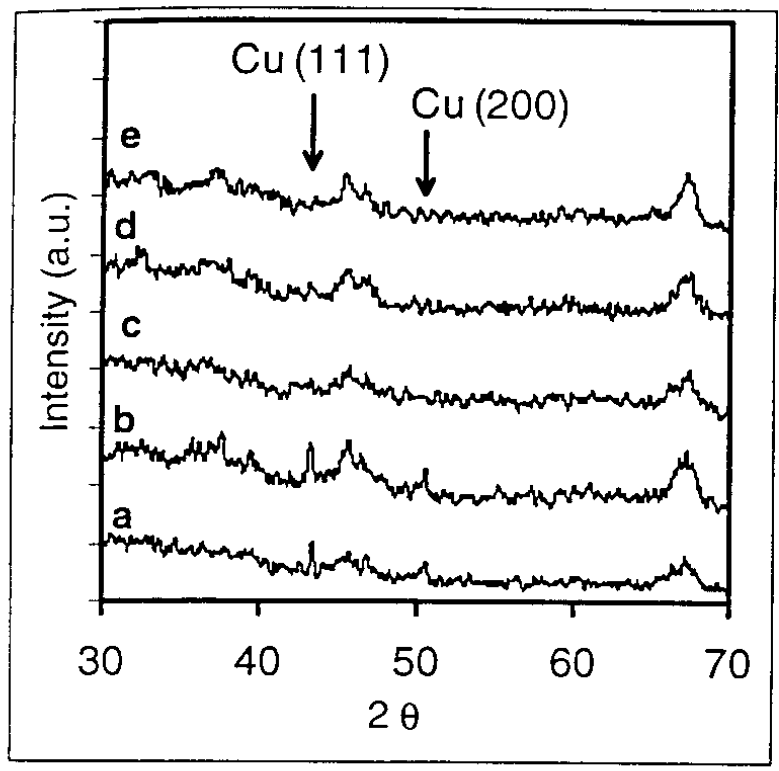

Fig. 1. XRD patterns of the $\mathrm{CuRh} / \mathrm{Al}$ catalysts: (a) $\mathrm{Cu}$, (b) CuRh100, (c) CuRh500, (d) CuRh1000, (e) CuRh2000.

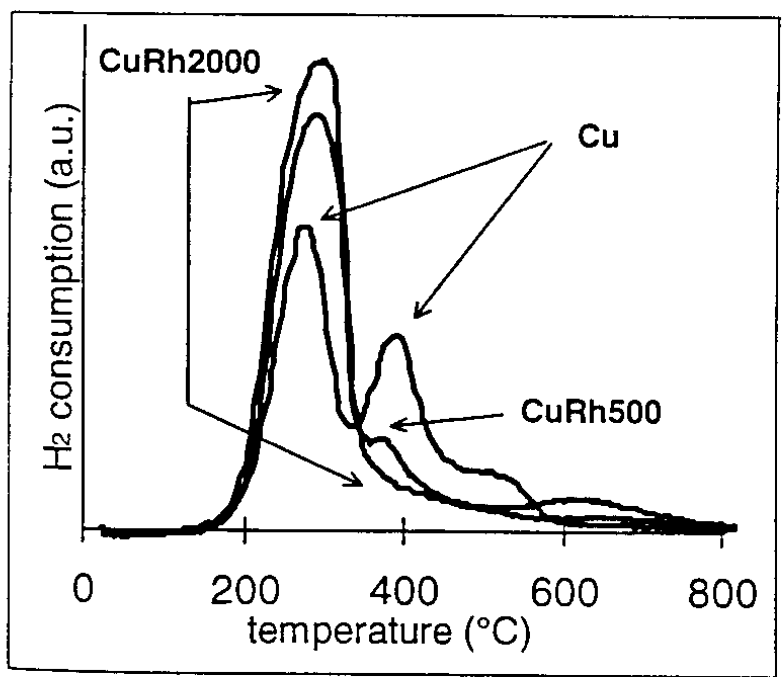

Fig. 3. TPR profiles of the $\mathrm{CuRh} / \mathrm{Al}$ catalysts.

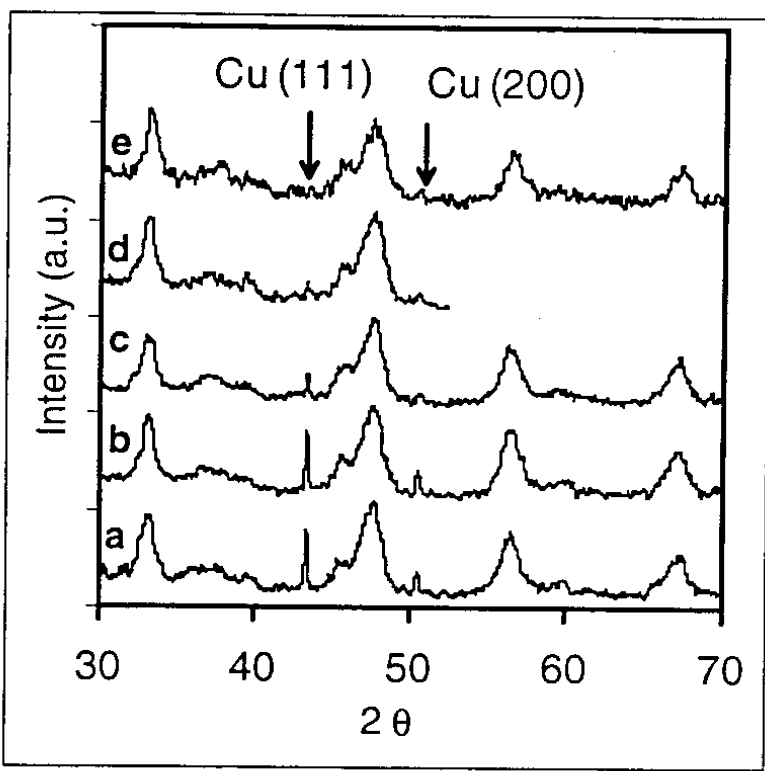

Fig. 2. XRD patterns of the $\mathrm{CuRh} / \mathrm{CeAl}$ catalysts: (a) $\mathrm{Cu}$, (b) CuRh100, (c) CuRh500, (d) CuRh1000, (e) CuRh2000.

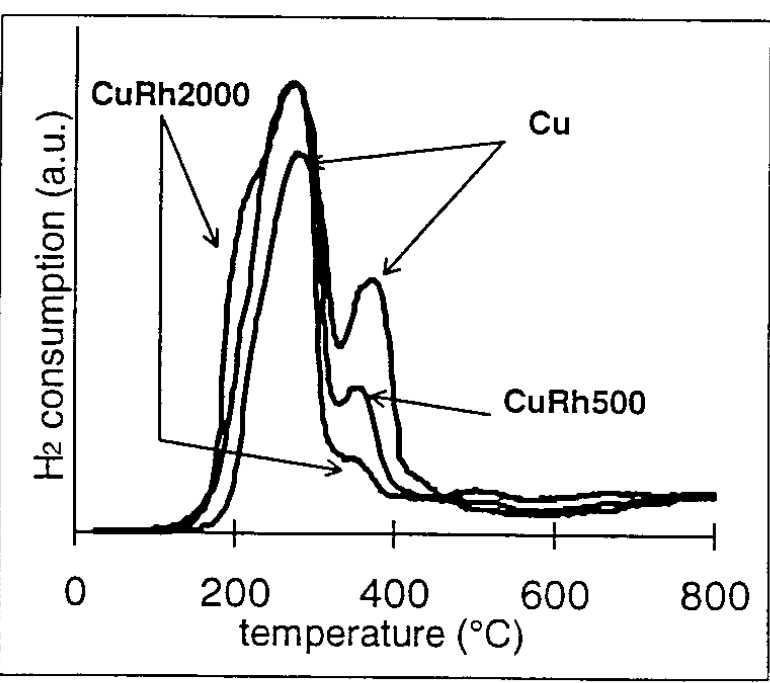

Fig. 4. TPR profiles of the $\mathrm{CuRh} / \mathrm{CeAl}$ catalysts. 
Figure 5 shows XRD patterns during in-situ reduction of the $\mathrm{Cu} / \mathrm{Al}$ sample. The quantitative evolution of the phases $\mathrm{CuO}$ and $\mathrm{Cu}$ are given Fig. 6 . No change in the diffraction pattern is noted between the calcined sample and after reduction at $200^{\circ} \mathrm{C}$, with only $\mathrm{CuO}$ being detected. After reduction at $220^{\circ} \mathrm{C}, \mathrm{Cu}^{0}$ peaks are coming out with $\mathrm{CuO}$ peaks still remaining but with a lower intensity. No formation of $\mathrm{Cu}_{2} \mathrm{O}$ is evidenced. After reduction at $250^{\circ} \mathrm{C}$, peaks of $\mathrm{CuO}$ totally disappear while those of $\mathrm{Cu}^{0}$ increase. $\mathrm{Cu}_{2} \mathrm{O}$ is still undetected. Upon increasing the reduction temperature above $250^{\circ} \mathrm{C}$, only the increase of the $\mathrm{Cu}^{0}$ peaks is observed, smoothly between 250 and $500^{\circ} \mathrm{C}$, more abruptly between 500 and $680^{\circ} \mathrm{C}$. This increase in the copper peaks intensity can be assigned to the sintering of metallic copper particles initially not detected.

\section{DISCUSSION}

The presence of two peaks in the TPR profiles and their modifications upon addition of rhodium have to be discussed in relation to the XRD results and literature data. The in-situ $\mathrm{XRD}$ experiment has clearly shown that for the $\mathrm{Cu} / \mathrm{Al}$ sample, only the peaks of metallic $\mathrm{Cu}$ have appeared simultaneously with the vanishing of the $\mathrm{CuO}$ phase, without the formation of $\mathrm{Cu}_{2} \mathrm{O}$. Thus, the $\mathrm{CuO}$ particles which are large enough to diffract have a reduction process that occurs in a single step. The formation of $\mathrm{Cu}^{\mathrm{I}}$ species as an intermediate step has been proposed for $\mathrm{Cu} /$ zeolite solids [6], for some $\mathrm{Cu} / \mathrm{SiO}_{2}$ [7] or $\mathrm{Cu} / \mathrm{Al}_{2} \mathrm{O}_{3}$ catalysts [8]. It is not evidenced in the present study, although it is not possible to completely discard that highly dispersed copper not detected by XRD could be reduced through the formation of a $\mathrm{Cu}^{+}$ intermediate.

A two/three peaks reduction TPR profile has often been found in literature for supported copper catalysts and is generally interpreted as due to the successive reduction of small clusters and/or isolated ions at low temperature, followed by the reduction of larger particles at higher temperature [5, 9-11 and references therein]. Increasing the $\mathrm{Cu}$ content so that excess copper formed bulk CuO particles evidenced by XRD or STEM/EDX increased the high temperature peak intensity $[10,11]$. We can interpret our results in the same way by attributing the second TPR peak at $375^{\circ} \mathrm{C}$ to the reduction of bulk $\mathrm{CuO}$ whereas the first one at $270^{\circ} \mathrm{C}$ corresponds to the reduction of small $\mathrm{CuO}$ clusters and isolated $\mathrm{Cu}^{2+}$ ions, undetectable by XRD. This attribution is in agreement with the results of Dumas et al. who observed on a $6 \mathrm{wt} \% \mathrm{Cu} / \mathrm{alumina}$ catalyst a similar profile with peaks at 242 and $312^{\circ} \mathrm{C} \mathrm{[5].}$ Increasing the $\mathrm{Cu}$ loading to $10 \%$ was accompanied by a much higher reduction peak at $312^{\circ} \mathrm{C}[5]$. The fact that higher temperatures are found in the present study may be attributed to a higher heating rate during the TPR $\left(20^{\circ} \mathrm{C} \mathrm{min}^{-1}\right.$ instead of $\left.5^{\circ} \mathrm{C} \mathrm{min} \mathrm{min}^{-1}\right)$. The differences in the operating conditions used can also explain the shift in the temperature range observed for the in situ XRD reduction of $\mathrm{CuO}$ particles which occurs at about $250^{\circ} \mathrm{C}\left(\mathrm{H}_{2}\right.$ partial pressure five times higher, double flow rate and cumulated heating times above $200^{\circ} \mathrm{C}$ corresponding to several minutes, whereas the heating rate was $20^{\circ} \mathrm{C} \mathrm{min}^{-1}$ in the TPR experiments).

The attribution of the second peak to the reduction of $\mathrm{CuO}$ particles and its decrease when the rhodium content increases is supported by XRD data on the initial calcined samples. As shown in Fig.7, a $\mathrm{CuO}$ phase could be evidenced on the $\mathrm{Cu} / \mathrm{CeAl}$ while it could not be detected with the CuRh1000/CeAl, showing that rhodium addition limits the formation of $\mathrm{CuO}$ particles.

This is also in line with the XRD spectra of the reduced catalysts. As evidenced in Fig. 8 for the $\mathrm{CuRh} / \mathrm{CeAl}$ catalysts, there is a linear relationship between the intensity of the (111) 


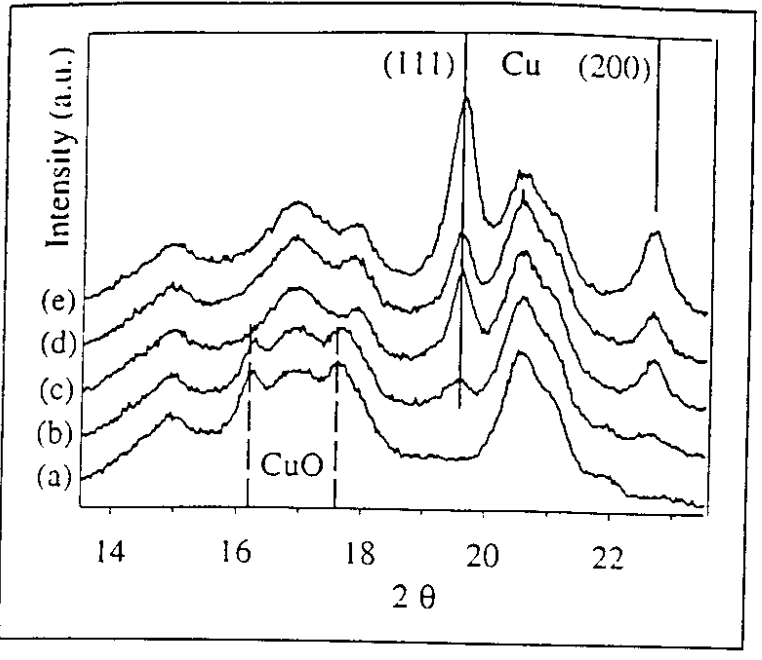

Fig. 5. In-situ XRD patterns of the $\mathrm{Cu} / \mathrm{Al}$ sample reduced at (a) $200^{\circ} \mathrm{C}$, (b) $220^{\circ} \mathrm{C}$, (c) $240^{\circ} \mathrm{C}$, (d) $260^{\circ} \mathrm{C}$ and (e) $680^{\circ} \mathrm{C}$.

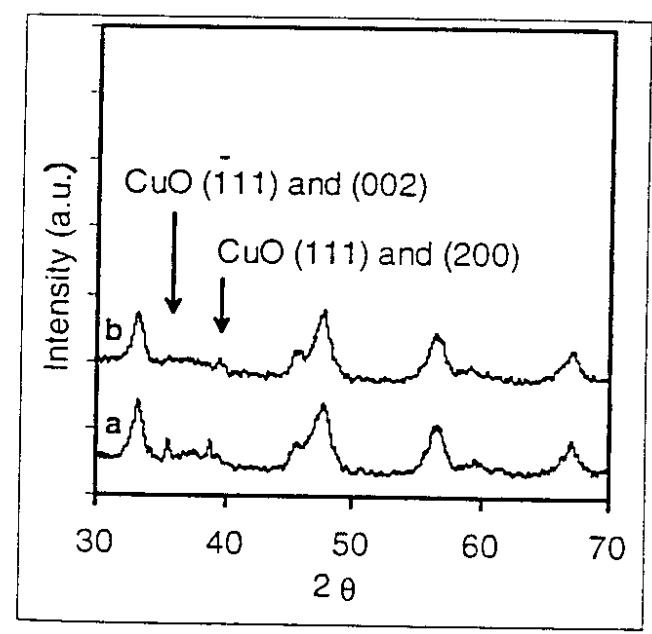

Fig. 7. XRD patterns of the calcined CuRh/Al catalysts: (a) $\mathrm{Cu}$, (b) CuRh 1000.

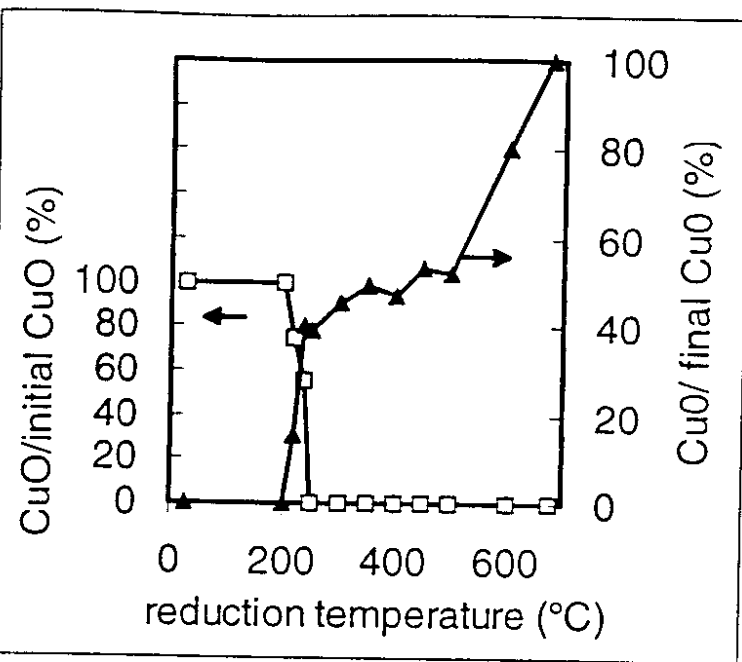

Fig. 6. $\mathrm{Cu} / \mathrm{Al}$ : evolution of the $\mathrm{CuO} /$ initial $\mathrm{CuO}$ (calcined sample) ( $\square$ ) and the $\mathrm{Cu}^{0} /$ final $\mathrm{Cu}^{0}$ (sample reduced at $\left.680^{\circ} \mathrm{C}\right)(\mathbf{\Lambda})$ determined by integration of the XRD peaks of $\mathrm{CuO}$ and $\mathrm{Cu}^{0}$.

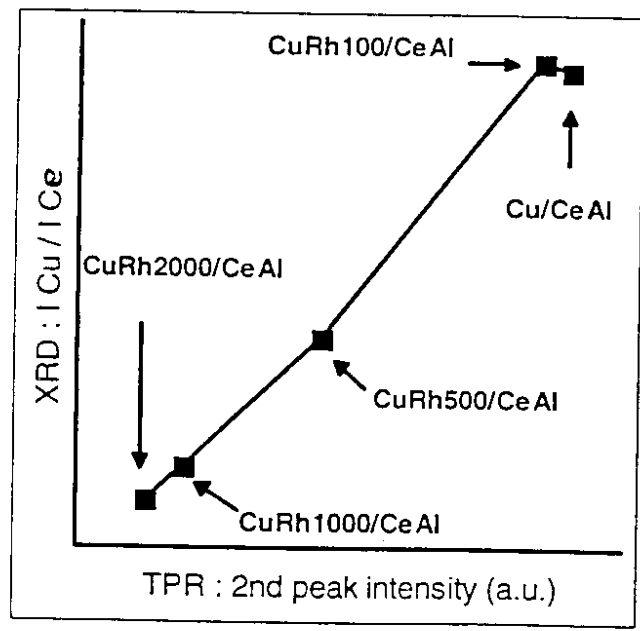

Fig. 8. Relationship between the height of the (111) Cu diffraction line $\left(\mathrm{CeO}_{2}\right.$ as internal standard) and the intensity of the $2^{\text {nd }}$ TPR peak for the $\mathrm{CuRh} / \mathrm{CeAl}$ catalysts. 
$\mathrm{Cu}$ diffraction line and the intensity of the second TPR peak at $375^{\circ} \mathrm{C}$. The same tendency is observed with the CuRh/Al catalysts, for which no $\mathrm{Cu}$ diffraction peaks are detectable for [Rh] $>100 \mathrm{ppm}$ in agreement with the low intensity of the second TPR peak observed for these catalysts. Since no variation of the breadth of the XRD $\mathrm{Cu}$ peaks could be measured, this decrease of the $\mathrm{Cu}$ diffraction peaks indicate a decrease in the number of large $\mathrm{Cu}$ particles.

These results clearly show that addition of small amounts of rhodium inhibits the formation of $\mathrm{CuO}$ particles expely to give large size copper particles by reduction. It favours the formation of small clusters which are more easily reduced at lower temperatures.

\section{CONCLUSION}

The addition of small amounts of rhodium to a copper-alumina catalyst does not basically modify the reduction mechanism based on the successive reduction of i) the isolated ions and small clusters and then ii) the bulk copper oxide. However, the structure of the catalyst is deeply changed since the presence of rhodium decreases the number of large size copper oxide particles. In this sense, it can be said that rhodium assists in the reduction because it favors the formation of small clusters which are reducible at lower temperature. This effect of rhodium addition resulting in a more dispersed structure of copper is more easily observed when copper is supported on ceria-alumina than on alumina. The redox nature of ceria does not deeply modify the reduction process at low temperature.

Acknowledgements: Rhodia is gratefully acknowledged for supplying the alumina and ceriaalumina supports.

\section{REFERENCES}

1. P.Y. Lin, M. Skoglundh, L. Lowendahl, J.E. Dahl, K. Jansson and M. Nygren, Appl. Catal. B: Environmental, 6 (1995) 237.

2. S. Bernal, J.J. Calvino, G.A. Cifredo, J.M. Rodriguez-Izquierdo, V. Perrichon and A. Laachir, J. Catal., 137 (1992) 1.

3. Lj. Kundakovic and M. Flytzani-Stephanopoulos, J. Catal., 179 (1998) 203.

4. E. Rogemond, R. Frety, V. Perrichon, M. Primet, S. Salasc, M. Chevrier, C. Gauthier and F. Mathis, J. Catal., 169 (1997) 120.

5. J.M. Dumas, C. Geron and J. Barbier, Applied Catalysis 47 (1989) L9.

6. C. Torre-Abreu, M.F. Ribeiro, C. Henriques and G. Delahay, Appl. Catal. B:

Environmental., 12 (1997) 249.

7. E.D. Guerreiro, O.F. Gorriz, J.B. Rivarola and L.A. Arrua, Applied Catal. A: General, 165 (1997) 259.

8. H. Praliaud, S. Mikhailenko, Z. Chajar and M. Primet, Appl. Catal. B: Environmental, 16 (1998) 359.

9. W.P. Dow, Y.P. Wang and T.J. Huang, J. Catal., 160 (1996) 155.

10. R.X. Zhou, X.Y. Jiang, J.X. Mao and X.M. Zheng, Appl. Catal. A: General, 162 (1997) 213.

11. Lj. Kundakovic and M. Flytzani-Stephanopoulos, Appl. Catal. A: General, 171 (1998) 13. 